\title{
Effect of cooking durations on amino acids profile of flamboyant seed meal (Delonix regia) for animals feeding
}

\author{
Guluwa, L. Y. ${ }^{1 \star}$, Damter, S. A. ${ }^{1}$, Onazi, B. O. ${ }^{2}$, Damar, I. J. ${ }^{1}$ and Dalokom, Y. D. ${ }^{1}$ \\ ${ }^{1}$ College of Agriculture, Garkawa, Plateau State, Nigeria. \\ ${ }^{2}$ Federal College of Education Gusau, Zamfara State, Nigeria. \\ *Corresponding author. Email: lukayangka@gmail.com
}

Copyright ( 2019 Guluwa et al. This article remains permanently open access under the terms of the Creative Commons Attribution License 4.0, which permits unrestricted use, distribution, and reproduction in any medium, provided the original work is properly cited.

Received 12th January, 2019; Accepted 15th February, 2019

\begin{abstract}
This study assesses the amino acids profile of Flamboyant seeds (Delonix regia) collected at the premises of Plateau State College of Agriculture, Garkawa. Flamboyant seed meal (FSM) were cooked for 0, 30, 60, 90 and 120 mins as treatments and replicated three times in a completely randomized design (CRD). It was then analyses for both essential and non-essential amino acids profile using Technicon sequential Multi-sample Amino Acid Analyzer (TSM) at University of Jos, Plateau State. Cooking started at $100^{\circ} \mathrm{C}$ for $0,30,60,90$ and 120 minutes. Results showed significant $(p<0.05)$ increase in the amino acids profile from 0 to 60 minutes and decline thereafter as cooking duration increased. In addition, cooking duration beyond 60 mins denatured the amino acid profile. In conclusion, 60 mins cooking duration had the best, therefore, it is recommended to be use in animal feeding since critical amino acids like lysine and methionine had higher values over others cooking durations.
\end{abstract}

Keywords: Amino acids cooking, duration, flamboyant, seeds.

\section{INTRODUCTION}

Delonix regia in spite of it potential to serve as livestock feed and its relative abundance has remained largely unused for animal nutrition (Ologhobo et al., 1993). Reports also showed that Delonix regia is nutritive and good for both nutrition and industrial usage. The seeds are good source of oil, energy-rich, good for consumption and can be used as protein supplement but may pose cardiovascular risk due to its high sodium-to-potassium ratio (Oyedeji et al., 2017). Bake et al. (2014) reported that 10 to $15 \%$ inclusion of Delonix regia seed meal improved growth performance and nutrient utilization of Nile tilapia fingerlings.

Wikipedia (2014) reported that Delonix regia has nitrogen fixing and soil improvement properties. Animals obtained proteins by eating plants or other animals byproducts. The ideal protein is usually defined as the perfect ratio among the essential amino acids required for maintenance and production (Arun and Bahl, 2005).
Components of many natural foods are affected by fruit maturity, water stress, mineral nutrition, climatic condition, field treatment and light-dark transition (Foyer et al., 2003; Fritz et al., 2006). Amino acids after absorption are used for tissue protein, enzymes, hormones, other metabolites synthesis and the carbon skeleton used for energy by the animals (Church and Pond, 1988). Essential amino acids are needed by the animal but cannot be synthesized by the animal in the amount needed and so must be present in the protein of the feed (Babington, 2000). Non-essential amino acids are needed by the animals but can be formed from other amino acids by the animal and so do not have to be present in the feed.

Lysine is one of the first limiting amino acid in monogastric nutrition often considered critical when balancing ration and is necessary building block for all protein in the body. L-lysine also plays significant role in calcium absorption, building muscle of protein and the 
Table 1. Effect of cooking on essential Amino acid profile of cooked flamboyant seed meal.

\begin{tabular}{|c|c|c|c|c|c|c|}
\hline \multirow{2}{*}{$\begin{array}{l}\text { Essential } \\
\text { Amino acids }\end{array}$} & \multicolumn{5}{|c|}{ Cooking duration (minutes) } & \multirow{2}{*}{ SEM } \\
\hline & CFSMo & $\mathrm{CFSM}_{30}$ & CFSM60 & $\mathrm{CFSM}_{90}$ & CFSM $_{120}$ & \\
\hline Lysine & $3.27^{d}$ & $3.30^{d}$ & $4.10^{\mathrm{a}}$ & $3.52^{\mathrm{c}}$ & $3.71^{b}$ & $0.08^{*}$ \\
\hline Histidine & $1.75^{\mathrm{c}}$ & $1.91^{b c}$ & $2.22^{\mathrm{a}}$ & $1.94^{\mathrm{ab}}$ & $2.00^{\mathrm{b}}$ & $0.05^{*}$ \\
\hline Thyrosine & $1.66^{d}$ & $1.82^{\mathrm{c}}$ & $2.32^{\mathrm{a}}$ & $1.99 \mathrm{~b}$ & $1.99^{b}$ & $0.06^{*}$ \\
\hline Leucine & $6.57^{\mathrm{e}}$ & $6.69^{d}$ & $7.92^{\mathrm{a}}$ & $7.04^{\mathrm{c}}$ & $7.81^{\mathrm{b}}$ & $0.15^{*}$ \\
\hline Phynelalanine & $4.31^{\mathrm{e}}$ & $4.40^{d}$ & $4.93^{\mathrm{a}}$ & $4.58^{\mathrm{c}}$ & $4.75^{\mathrm{b}}$ & $0.06^{*}$ \\
\hline Arginine & $6.98^{e}$ & $7.15^{d}$ & $8.34^{a}$ & $7.49^{c}$ & $7.83^{\mathrm{b}}$ & $0.13^{*}$ \\
\hline Valine & $3.83^{b}$ & $4.02^{\mathrm{b}}$ & $4.72^{\mathrm{a}}$ & $3.99^{b}$ & $4.69^{a}$ & $0.11^{*}$ \\
\hline Methionine & $1.80^{\mathrm{b}}$ & $1.80^{\mathrm{b}}$ & $1.96^{\mathrm{a}}$ & $1.88^{\mathrm{ab}}$ & $1.88^{\mathrm{ab}}$ & $0.02^{*}$ \\
\hline Isoleucine & $4.11^{\mathrm{b}}$ & $3.91^{d}$ & $4.21^{a}$ & $3.98^{c}$ & $4.01^{\mathrm{c}}$ & $0.03^{*}$ \\
\hline
\end{tabular}

${ }^{*} a, b, c, d, e$ Means on the same row with different superscripts are significantly different $(P<0.05), S E M=S t a n d a r d$ error of mean, $T_{1}=u n-$ cooked flamboyant seed meal $=\mathrm{CFSM}_{0}, \mathrm{~T}_{2}=\mathrm{CFSM}_{30}$ cooked flamboyant seed meal for 30 minute, $\mathrm{T}_{3},=\mathrm{CFSM}_{60}$ cooked flamboyant seed meal for 60 minute, $T_{4}=C_{\text {CFSM }}$ cooked flamboyant seed meal for 90 minute, $T_{5}=C_{12}$ CM $_{120}$ cooked flamboyant seed meal for 120 minute, CFSM = Cooked Flamboyant seed meal.

body's production of hormones, enzymes and antibodies (Wikipedia, 2013). Lysine supplementation allows for the use of lower-cost plant protein while maintaining high growth rates limiting the pollution from nitrogen excretion (Abelson, 1999). A deficiency of lysine causes reduced appetite, loss of weight, poor feed efficiency, rough dry hair coat, general emaciated condition and produces abnormal feathering in birds (Church and Pond, 1988).

Administration of methionine improved the pathological consequences of methionine deprivation ( $\mathrm{Oz}$ et al., 2008). Deficiency of this amino acids result in reduced rate of growth, efficiency of feed utilization and produces fatty liver (Church and Pond, 1988).

Amino acids such as tryptophan act as building blocks in protein biosynthesis and also function as a biochemical precursor for serolin, niacin and auxin compounds and deficiency of tryptophan in the diet causes a loss in the weight, poor feed consumption, depraved appetite, rough hair coat and symptoms of inanition in the pig (Wikipedia, 2014).

Thus, the objective of this study was designed to evaluate the response of cooking durations on amino acids profile of flamboyant seed meal.

\section{MATERIALS AND METHODS}

\section{Test ingredients preparation}

Flamboyant seeds (Delonix regia) were collected from the premises of Plateau State College of Agriculture Garkawa. The pods were crushed to get the seeds, then, further divided into five equal parts and process via cooking at 0 , $30,60,90$ and 120 minutes (cooking started at $100^{\circ} \mathrm{C}$ for $0,30,60,90$ and 120 minutes). Afterward, the seeds were sun dried and milled to obtain cooked flamboyant seed meal coded as CFSMo, $\mathrm{CFSM}_{30}, \mathrm{CFSM}_{60}, \mathrm{CFSM}_{90}$, and $\mathrm{CFSM}_{120 .}$

\section{Determination of Amino acid profile}

The amino acid profile was determined using the method described by Benitez (1989). The samples were dried to a constant weight, defatted, hydrolysed, evaporated in a rotary evaporator and loaded into the Technicon Sequential Multi-sample Amino Acid Analyzer (TSM). Defatted sample was done using the method described by AOAC (2006). The amino acid profile of flamboyant seeds meals were analysed for the presence of essential amino acids (lysine, histidine, arginine, valine, methionine, isoleucine, leucine, thyrosine and phynelalanine) and nonessential amino acids such as alanine, aspartic acids, cystine, glutamic acid, glycine, proline, serine and tyrosine. The cooking duration were replicated three times in a completely randomized design.

\section{Statistical analysis}

Data obtained were subjected to analysis of variance (ANOVA) using the SPSS (2010) statistical software where significance differences were observed. Means were separated using Duncan Multiple Range Test (DMRT) as outlined by SPSS (2010).

\section{RESULT AND DISCUSSIONS}

Table 1 reveals the effect of cooking durations on essential amino acids profile of cooked flamboyant seed (Delonix regia). Cooking duration had significant $(p<0.05)$ effects on lysine, histidine, arginine, valine, methionine, isoleucine, leucine, thyrosine and phynelalanine as cooking duration increased.

The lysine content of flamboyant seed meal was significantly $(p<0.05)$ higher for 60 minutes cooking compared to other durations of cooking. The value obtained in this study fall within the ranges values of 3.14 
Table 2. Effect of cooking duration on non-essential amino acids profile of cooked flamboyant seed meal.

\begin{tabular}{|c|c|c|c|c|c|c|}
\hline \multirow{2}{*}{$\begin{array}{l}\text { Non-essential } \\
\text { Amino acids }\end{array}$} & \multicolumn{5}{|c|}{ Cooking duration (minutes) } & \multirow{2}{*}{ SEM } \\
\hline & CFSMo & $\mathrm{CFSM}_{30}$ & $\mathrm{CFSM}_{60}$ & CFSM90 & $\mathrm{CFSM}_{120}$ & \\
\hline Aspartic acid & $8.59^{e}$ & $9.03^{a}$ & $8.96^{\mathrm{b}}$ & $8.84^{c}$ & $8.78^{d}$ & $0.04^{*}$ \\
\hline Alanine & $3.73^{b}$ & $4.43^{a}$ & $3.78^{\mathrm{cd}}$ & $3.81^{c}$ & $3.82^{c}$ & $0.07^{*}$ \\
\hline Threonine & $3.41^{d}$ & $3.58^{a}$ & $3.61^{a}$ & $3.47^{c}$ & $3.53^{b}$ & $0.02^{*}$ \\
\hline Serine & $3.53^{\mathrm{e}}$ & $3.58^{d}$ & $4.00^{\mathrm{a}}$ & $3.67^{c}$ & $3.70^{b}$ & $0.04^{*}$ \\
\hline Glutamic acids & $12.58^{\mathrm{c}}$ & $12.65^{c}$ & $13.34^{a}$ & $12.85^{\mathrm{bc}}$ & $12.81^{b c}$ & $0.10^{*}$ \\
\hline Proline & $2.55^{c}$ & $2.78^{e}$ & $3.48^{a}$ & $3,02^{b}$ & $3.02^{b}$ & $0.08^{*}$ \\
\hline Glycine & $2.01^{c}$ & $5.17^{\mathrm{bc}}$ & $5.68^{a}$ & $5.35^{b}$ & $3.50^{d}$ & 0.20 * \\
\hline Cystine & $1.59^{b}$ & $1.66^{\mathrm{ab}}$ & $1.73^{\mathrm{a}}$ & $1.65^{\mathrm{ab}}$ & $1.66^{\mathrm{ab}}$ & 0.02 * \\
\hline
\end{tabular}

${ }^{*} a, b, c, d, e$ Means on the same row with different superscripts are significantly different $(P<0.05), S E M=S t a n d a r d$ error of mean, $T_{1}=u n-$ cooked flamboyant seed meal $=\mathrm{CFSM}_{0}, \mathrm{~T}_{2}=\mathrm{CFSM}_{30}$ cooked flamboyant seed meal for 30 minute, $\mathrm{T}_{3},=\mathrm{CFSM}_{60}$ cooked flamboyant

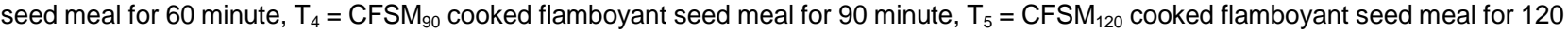
minute, CFSM = Cooked Flamboyant seed meal.

to $6.35 \%$ of local and industrial palm kernel meal as reported by Bello et al. (2008). Flamboyant seeds might be of good biological value for monogastric nutrition if well processed to reduce anti-nutritional content present in it as reported by Alemede et al. (2010).

The histidine content increased as cooking duration increased from 0 to 60 minutes and thereafter declined. Cooking duration at 60 minutes had the highest value of $2.22 \%$ for histidine. In addition, 60 minutes cooking time produces the best results and statistically higher for arginine, leucine and phynelalanine contents. This may suggest that normal growth and efficiency of feed utilization will be supported by including flamboyant seed meal in the diet of monogastric animals, especially, poultry and swine. The arginine content of flamboyant seed meal irrespective of cooking duration was higher than 3.2 and $5.0 \%$ of soya bean meal and groundnut cake respectively (Aduku, 1993). It also appears that cooking duration improves its leucine content over $6.39 \%$ of industrial palm kernel meal (Bello et al., 2008).

Increased in the duration of cooking beyond 60 minutes cause significant $(p<0.05)$ increase in methionine content of flamboyant seed meal. This may support metabolism processes that will aid in promoting efficiency of feed utilization to support gain in body weight. Only 60 minutes cooking time cause significant increase in isoleucine content of flamboyant seed. Significant $(p<0.05)$ increase was also notice for tyrosine content of flamboyant seeds cooked at varying interval. However, 60 minutes cooking time produce the best result but later decline as cooking duration increased.

Non-essential amino acids profile of flamboyant seed meal is presented in Table 2. Cooking duration had significant $(p<0.05)$ effects across all the parameters as duration of cooking increased from 0 to 120 minutes. The result indicates that 30 minutes cooking duration were significantly $(p<0.05)$ higher for aspartic acid and alanine and decline as duration of cooking increased. Steady increased from 0 to 60 minutes were noticed for threonine, serine, glutamic acids, proline, glycine and cystine contents of cooked flamboyant seed meal. However, 60 minutes cooking duration were recorded as the best. The results of this study portrayed flamboyant seeds meal as a useful feedstuff if cooked for 60 minutes. Higher percentage availability of Glutamic acids in this study may help in the synthesis and metabolism of nucleotides and amino acids.

\section{Conclusion}

Cooking cause modification in the primary structures of protein in flamboyant seed meal, and beyond 60 minutes denaturate the protein content. Cooking duration at 60 minutes produced the best among others cooking duration. With this improvement in the amino acids profile of cooked flamboyant seed meal, its utilization in poultry, pig and rabbit nutrition will go a long way to reduce feed cost and to make animal protein available to the teeming population. Amino acids profile of cooked flamboyant seed meal obtained in this study will provide nutritionist with valuable information on how to formulate a diet in order to maximize animal performance.

\section{Recommendation}

Cooking as a processing method gave higher values of amino acids over the raw seeds. It is therefore recommended that cooked flamboyant seed meal should be use as animal feeds resource because of its potential. Therefore, sixty (60) minutes cooking duration is recommended for feeding trial since critical amino acids like lysine and methionine had higher values over ground nut cake and soya bean meal.

\section{CONFLICT OF INTEREST}

The authors declare that they have no conflict of interest. 


\section{REFERENCES}

Abelson, P. (1999). A potential Phosphate crisis. Science, 283 (5410), 2015.

Aduku, A. O. (1993). Tropical Feedstuffs: Nutrient Analysis Table. Ahmadu Bello University, Zaria Nigeria.

Alemede, I. C., Adama, J. Y., Ogunbajo, S. A., \& Abdullahi, J. (2010). Haematological parameters of Savanna brown does fed varying dietary levels of flamboyant tree seed meal. Pakistan Journal of Nutrition, 9(2), 167-170.

AOAC (2006). Association of Office Analytical Chemicals, Official method of Analysis of the AOAC (W. Horwitz Editor Eighteen Edition, Washington, D.C, AOAC.

Arun, B., \& Bahl, B. S. (2005). Advanced Organic Chemistry, Ram Nagar, New Delhi, India. Pp. 838-846.

Babington, O. E. (2000). Animal nutrition and feeding - A functional approach. Second edition. Rukzeal and Ruksons Associates memory press, 21 Rotibi street, Oweri, Imo state,Nigeria.

Bake, G. G., Martins, E. I., \& Sadiku, S. O. E. (2014). Nutritional evaluation of varying levels of cooked flamboyant seed meal (Delonix Regia) on the growth performance and body composition of Nile tilapia (Oreochromis Niloticus) fingerlings. Agriculture, Forestry and Fisheries, 3(4), 233-239.

Bello, K. M., Oywoye, E. O. \& Bogoro, S. E. (2008). Effect of processing on chemical composition of Palm Kernel meal. Proc 13th Ann. Conf. Anim. Sci. Assoc. Nig. Ahmadu Bello University, Zaria Nigeria. Pp. 114-117.

Benitez, L. V. (1989). Amino acid and fatty acid profiles in aquaculture nutrition studies. Fish Nutrition Research in Asia, Pp. 23-35.
Church, D. C., \& Pond, W. G. (1988). Basic nutrition and feeding. John Wiley and Sons. Pp. 348-359.

Foyer, C. H., Parry, M., \& Noctor, G. (2003). Markers and signals associated with nitrogen assimilation in higher plants. Journal of Experimental Botany, 54(382), 585-593.

Fritz, C., Mueller, C., Matt, P., Feil, R., \& Stitt, M. (2006). Impact of the $\mathrm{C}-\mathrm{N}$ status on the amino acid profile in tobacco source leaves. Plant, Cell and Environment, 29(11), 2055-2076.

Ologhobo, A. D., Apata, D. F., Oyejide, A., \& Akinpelu, O. (1993). Toxicity of raw limabeans (Phaseolus Lunatus L.) and limabean fractions for growing chicks. British Poultry Science, 34(3), 505-522.

Oyedeji, O. A., Azeez, L. A., \& Osifade, B. G. (2017). Chemical and nutritional compositions of flame of forest (Delonix regia) seeds and seed oil. South African Journal of Chemistry, 70, 16-20.

Oz, H. S., Chen, T. S., \& Neuman, M. (2008). Methionine deficiency and hepatic injury in a dietary steatohepatitis model. Digestive Diseases and Sciences, 53(3), 767-776.

SPSS (2010). Statistical package for Social Science. Release 15.0. User Manual. Microsoft Corporation USA.

Wikipedia (2013). Lysine. Wikipedia, the encyclopedia. Wikipedia (2014). Anti-nutrient. The free encyclopedia. 